\title{
POSTLUDE:
}

MEMORABILIA

What remains after the life and career of an archaeologist in-between? Most obviously perhaps, his writings. The three reports from his Indochina expeditions stand out as Olov Janse's most important academic oeuvre, but he also wrote more than sixty articles in Swedish, French, and English for academic journals, magazines, and newspapers. The most personal account of his life and work is found in his memoirs Ljusmannens gåta, which can be read in the Swedish original from $1959,{ }^{1190}$ or in a Vietnamese translation from 2001. ${ }^{1191}$ There are also the generous funds that Renée bequeathed in her final will to members of both their families, the Royal Swedish Academy of Letters, History and Antiquities, and to "Stiftelsen Thure Johan och Hilma Janses minnesfond", which every year award stipends to students graduating from Olov's old high school (now De Geergymnasiet) in Norrköping. But there are also more tangible traces of Olov's and Renée's lives and the archaeological work they pursued. And just as their lives were lived in movement and dispersion, the things they left behind are now dispersed over three continents. We have found them in unexpected places, often in fragile situations with little guarantees of future maintenance or preservation. These things work as memorabilia, mnemonic devices that carry stories, evoke personal memories, and produce echoes of the personal and professional endeavours of Olov and Renée Janse.

1190. Janse 1959 .

1191. Janse 2001. 


\section{The marble table}

Christina Janse Petersson lives with her husband Jan-Erik in a villa south of Söderköping. She is related to Olov Janse through the marriage between her grandmother Signe Andersson and Olov's father Thure Janse in July 1918. Thure adopted Signe's son Bengt - Christina's father - from a previous marriage, but Olov never warmed to his father's new family and was never close to his stepmother and stepbrother. When Thure Janse died, Olov was stuck on the Philippines on his way to the United States and could not return to Sweden until seven years later, when he was working for UNESCO in Paris. When he eventually returned in June 1947, he ended up in conflict with Signe over Thure's estate. ${ }^{1192}$ Unable to bring much in terms of furniture and large objects from his childhood home back to the United States, he urged Signe to pay him the equivalent of his share of the estate in cash and threatened to have it all sold at auction to release the cash value. Of all the furniture from his father's home he brought only a chest of drawers, which we believe is seen in the background of the cover photograph of this book. Yet despite all the resentment between them, Signe kept one special thing for him - a small table with a chess-patterned marble top, which can be seen next to his mother Hilma in the photo from his childhood home in Norrköping. ${ }^{1193}$ It was precious to his mother and, judging from its distinctive red colour, we believe that it was made of limestone from Marmorbrottet, the marble quarry where she was born.

Olov Janse never returned to col-

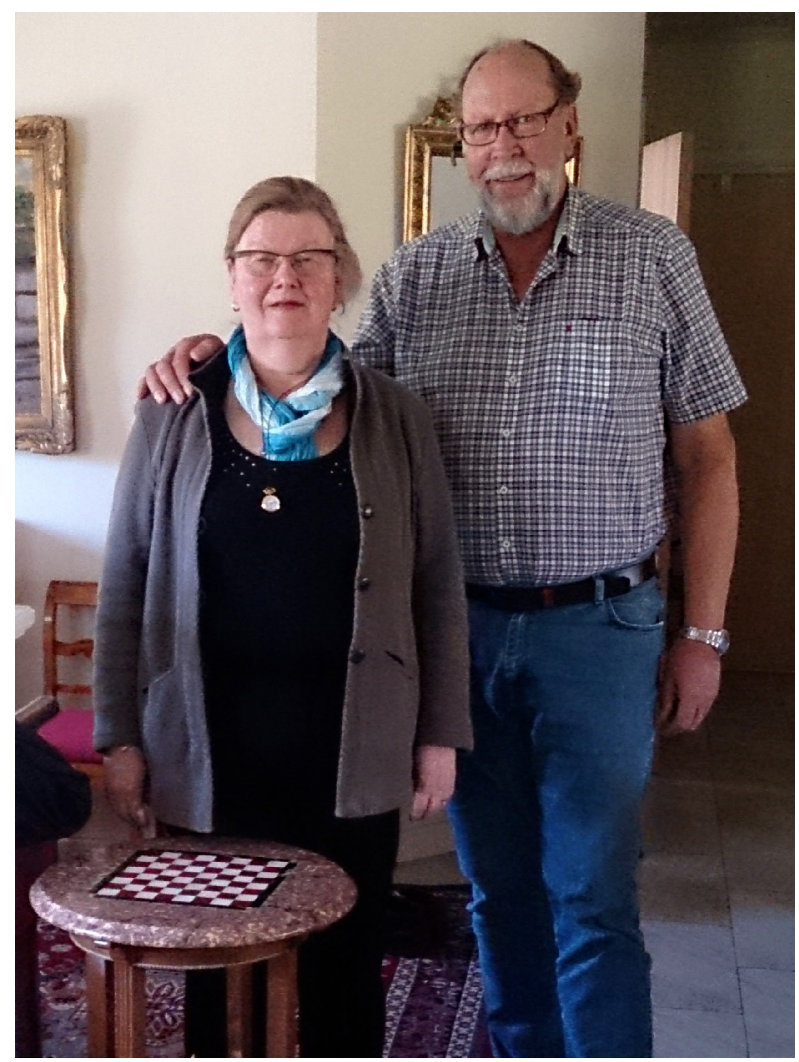

1192. Letters from O. Janse to R. Janse, 25 June 1947; 28 June 1947; 4 July 1947, in NAA: Janse 2001-29.

1193. See fig. 9 in the chapter "Otto and the Candy Factory". 
lect his table. ${ }^{1194}$ It now stands in Christina's and Jan-Erik's house near Söderköping, between Valdemarsvik where Thure Janse was born, and Norrköping where Olov Janse was born, fifty kilometres east of Marmorbrottet.

With its characteristic red limestone, which was also used to build the never-successful sugar factory that was part of the final fall of the Ljung Estate and now stands as a ghostly ruin by the main road, the table can be seen as a symbol of the great promises and broken dreams of the sugar and candy industry of the late nineteenth and early twentieth century - promises and failures that so severely affected Hilma's native family, built a life of hope and social standing for herself, and broke her husband after she died. For Christina and Jan-Erik, the table carries the story of an absent adventurous man, who never came to collect his belongings. ${ }^{1195}$

\section{Per Janse's archive}

When Renée Janse died on 21 December 2000, her estate was divided according to her testament. In the absence of children or other close relatives in the United States, most of their belongings were sold at auction and the total worth of the estate - more than US \$4,000,000 - was distributed to relatives in Russia and Sweden. ${ }^{1196}$ In Sweden, one of the beneficiaries was Per Janse, grandson of Olov's uncle Otto Janse. The testament came as a surprise to Per. As far as he can remember he had only met Olov and Ronny Janse once, when they came to visit his parents' home in Djursholm near Stockholm in August 1968 (fig. 83). He was 21 years old and has vivid memories of the visit. He found Olov sympathetic but did not warm to Renée, who he remembers spoke in racist terms of "blackies". ${ }^{1197}$ To him they gave the impression of being människor av värld - people of the world. ${ }^{1198}$

From the moment when he was first informed about the testament in

1194. Christina Janse Petersson also had in her possession a collection of photographs of Olov Janse and his family, which has been donated to Norrköping's City Archive.

1195. Interview with Christina Janse Petersson and Jan-Erik Petersson 30 September 2014 .

1196. Seventy per cent of the total estate was given to Renée's relatives in Russia. We have tried to locate the beneficiaries in Russia in order to learn more about her family and her early years in Krasnodar and Moscow, but all attempts have failed.

1197. Swe: Svartingar. Derogatory term for black persons.

1198. Interview with Per Janse, 11 April 2012. 


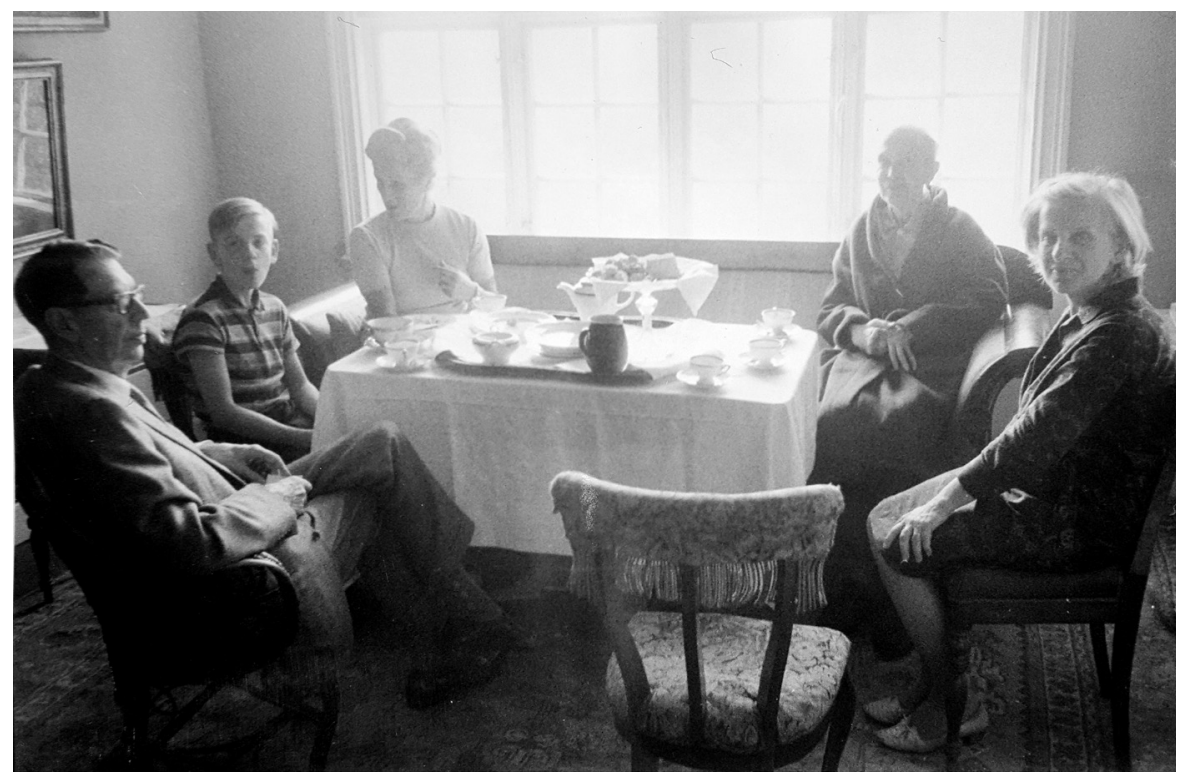

Fig. 83. Olov

and Renée

visiting Olov's

cousin Per Janse

in Djursholm

1968.

2001, Per Janse became something of a spokesperson for the legatees in Sweden. They were either descendants of Thure Janse's brother Otto and sister Theresia, or children or grandchildren of Ture and Birger Nerman. The testament aroused an interest among the family to know more about Olov's and Renée's lives, and Per asked the testament executor if he could have some of their personal documents to keep in the family, before they were donated to a public archive.

And so it happened that a collection of photographs and personal documents, mostly of an ageing Renée, often in a swimsuit, ended up in a green cardboard box in Solna north of Stockholm. Per Janse has kindly allowed us to use the photos and documents for our research, and they will be returned to the family on the completion of our project.

\section{Anders Nerman's bowl}

Ture Nerman had two sons, Bengt and Anders, and Birger Nerman had two daughters, Elisabeth and Agneta. Olov and Renée seem to have been fond of the children, and always mentioned them in their correspondence. They were godparents to Elisabeth, and the two sisters went to visit Olov and Renée in the United States in the early 1980s. Agneta, who had followed in her father's footsteps and become an archaeologist 
Fig. 84 .

Anders

Nerman

with Song

bowl.

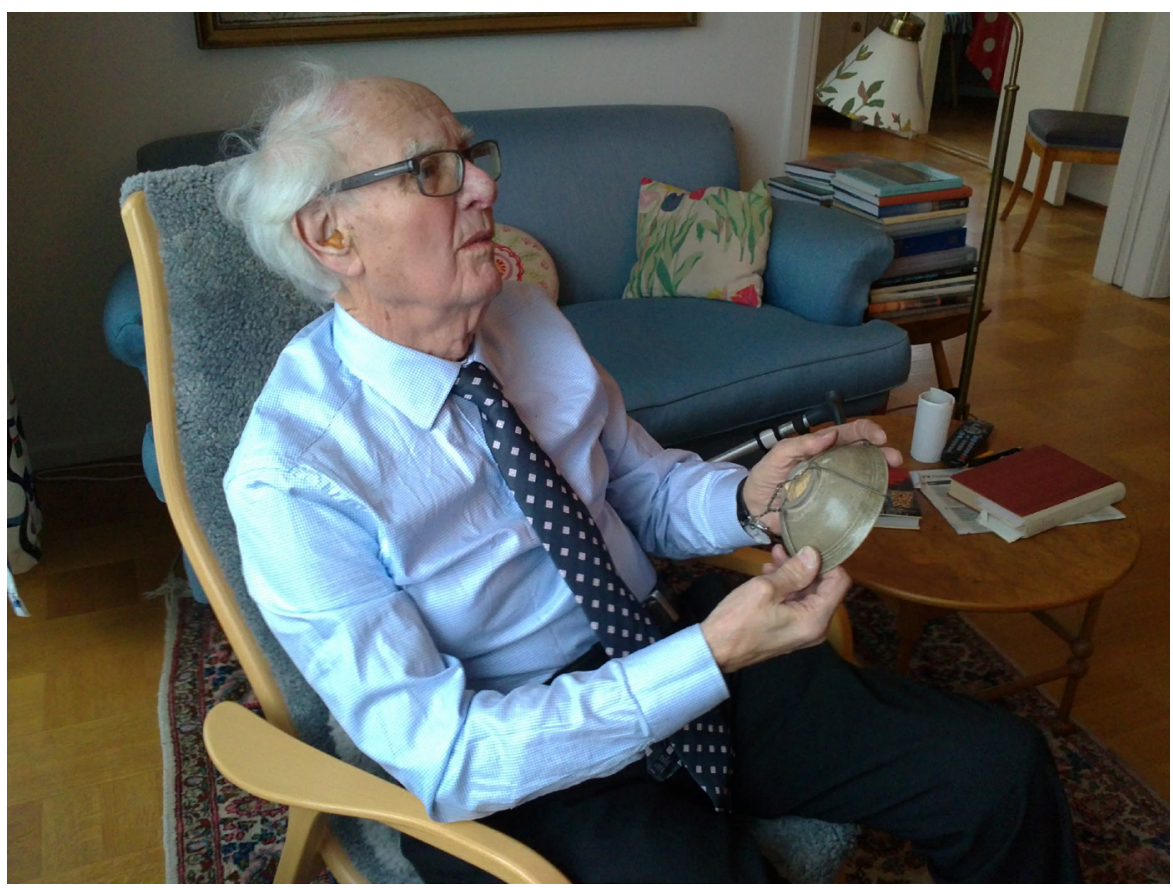

and museum director in Stockholm, visited them on the occasion of a Viking exhibition at the Metropolitan museum in New York. ${ }^{1199}$ She was 42 years old at the time, and recalls how Renée ordered her to take off her Indian-style tunic, dressed her in 1950 s clothing, and painted her eyebrows. Her older sister Elisabeth visited them in Washington, DC, a couple of years later. With a mixture of horror and delight she remembers Renée, who was then 80 years old, as a lovely but strong and dominant person "who drove her car like a madwoman". ${ }^{1200}$

Olov and Renée's relations with Ture Nerman's sons appear to have been less personal. When they were young boys, when Bengt was 13 and Anders 12 years old, he sent them each an ancient bowl as a souvenir from his excavations in Thanh Hoa. In several letters written in 1936 on their way to Indochina for the second expedition, Olov mentions the two bowls that would be delivered to Bengt and Anders Nerman by a friend returning to Stockholm from a visit to Paris. ${ }^{1201}$

1199. On display October 1980-January 1981.

1200. Interview with Elisabeth Nerman and Agneta Lundström, 11 February 2013.

1201. E.g. letter from Olov Janse to Ture and Nora Nerman, 13 October 1936. Arbetarrörelsens arkiv och bibliotek. Ture Nerman 3.1.7. Their mutual friend "Lunkan" (the editor of Folket $i$ Bild Ernst J. Lundqvist (1893-1958)) was given a third bowl. 
When we visited him in his stylish modern apartment in Stockholm late in the autumn 2012, Anders Nerman showed us the small green bowl that dates back to the Chinese Song Dynasty (AD 960-1279). ${ }^{1202}$ In the bottom was written (in Swedish): Gift 1936 from Janse. Grave find N. Annam/ Thanh Hoa. Song Dynasty. Despite their modest appearance, ceramics of the Song Dynasty are considered among the finest that have ever been produced. Anders Nerman had kept the bowl and knew that it was valuable, but he had no particular relation to it. Nor did he have any particular memories or recollections of Olov and Renée Janse, other than that she had "an exotic aura". Anders Nerman told us that his father's famous summer house at Grönvik (sometimes referred to as Bolshervik, where the red flag waved during the 1920s) on Blidö in the Stockholm archipelago, was in fact built of wood from boxes used to transport American cars imported to Sweden in the early twentieth century. The summer house, itself a rather interesting material parallel to the eclectic political life of its owner (Ture Nerman was first a devoted communist, turned into a social democrat, and ended his life promoting conservative American values and pro-NATO policies), was for long an object of desire at the centre of Olov and Ronny Janse's dreams of coming home to a life in Sweden. They had spent some of the happiest summers of their lives at Grönvik and in the Janse family's summer house at Skagshamn near Valdemarsvik. In the exile years, Olov and Ronny nutured plans to buy a piece of land and build a summer house near to Ture and Nora on Blidö. ${ }^{1203}$ But shortly after they became US citizens, they gave up all such plans and built an American summer cottage instead, at Cove Point in Maryland.

Bengt Nerman, who lived in the house in Grönvik, died in 2016. Anders Nerman died a year later, in June 2017. Both were 93 years old.

\section{Film reels}

Twelve years ago, when we first began to plan for the research project that eventually resulted in this book, we visited Per Janse's brother Carl Otto and his daughter Helga Janse in Östhammar north of Stockholm. Over coffee they described the internal relations of the Janse family, which we then knew very little about, when Carl Otto suddenly said: "and then of course we have the films". They pointed us to the study in the next

1202. See also Janse 1958: p. 101, pl. 66, pl. 80-82.

1203. Letter from O. Janse to Birger Nerman, 30 March 1938. Riksarkivet. Kartong 3. Korrespondens brev III 1935-1941. 


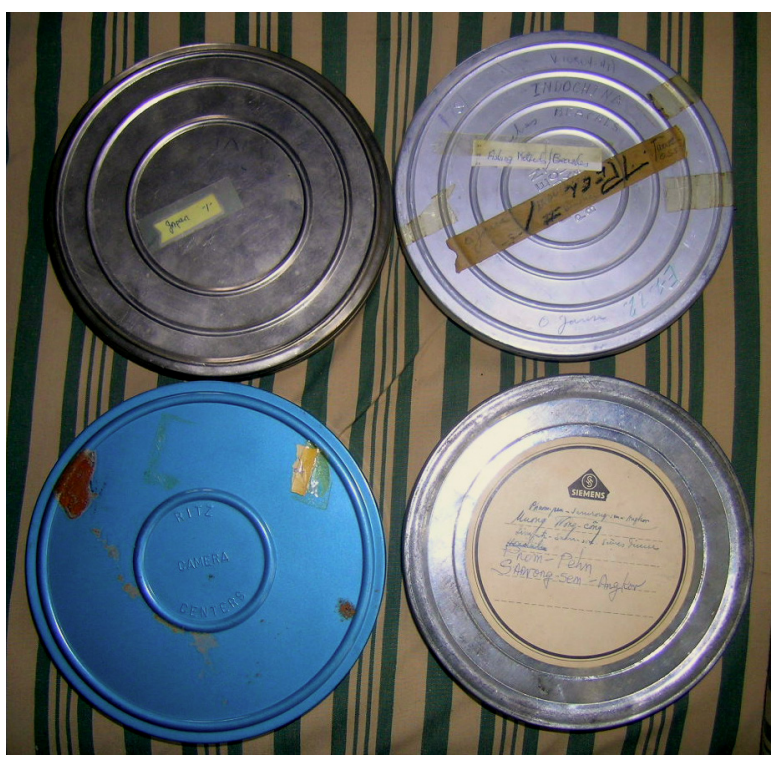

room, where there was a paper bag full of original film reels standing in a corner. Like Olov Janse at the discovery of the Lach-truong site in February 1935, we "nearly swooned" at the sight of them.

The reels, 16 in total, had been given to Carl-Otto when he visited Renée in Washington together with one of Helga's sisters, some years after Olov's death. The reels contained mostly original films, but also some purchased ones, dating from the 1930 s to the 1970 s. Some had scribbled notes attached to them that indicated their contents. After consulting the Swedish Television Ar-

Fig. 85. The film reels.

chives, the family was advised to submit the original films to the archive for safety reasons (since they contained chemicals which could lead to spontaneous combustion). Hence the films were donated to the television archive in Stockholm, ${ }^{1204}$ and DVD copies were made for the family and for our research purposes.

\section{Memories at Lach-truong}

In October 2005 we travelled to Thanh Hoa in northern Vietnam, to visit some of the sites Olov Janse excavated. First we spent a week in Hanoi, trying in vain to find traces of his presence there seventy years earlier. But despite considerable efforts supported by colleagues at the Institute of Archaeology, ${ }^{1205}$ we found nothing but vague fragments - a dedication on a frontispiece of an offprint in a library, a mention in a list of colonial-era archaeologists, and the like, but no proper documents, drawings, or other materials we hoped to be able to trace. We were told that all colonial-era documents and archives had been removed, reformed, or destroyed. The exception was the National History Museum (previously Musée Louis

1204. Swedish Television Archive. (C) SVT Arkiv.

1205. In Hanoi we received generous help from Dr Nguyen Kim Dzung and Dr Nguyen Tien Dong from the Institute of Archaeology. 
Finot), where we found a translated version of Janse's memoirs, ${ }^{1206}$ and many of his most important finds on display. Among them were ljusmannen, the candle-bearing kneeling figurine that gave name to his memoirs. But we were told by the museum staff that the museum buildings had undergone major interior reconstructions since colonial times, and that all artefacts from EFEO's excavations had been split and reorganized into new groups according to the material rather than the excavating archaeologist. Hence there was not much to find in terms of direct connections with Olov Janse and his Indochina expeditions. The search made us realize the extensive impact that a revolution and decades of socialist rule had on historical documentation. According to communist orthodoxy and in response to popular resentment towards colonial rule, the revolutionary government did not allow research or official storytelling about individuals in pre-revolution historic times, particularly individuals connected with French colonial rule. If the interest existed among Vietnamese researchers today, they were faced with the massive task of reconstructing historic data, and the hustle of breaking with decades of administrative tradition and social convenience.

Knowing that there was not much for us to find in Hanoi, we set off on a two-day excursion to the nearby province of Thanh Hoa. In the company of two Vietnamese colleagues, Dr Nguyen Tien Dong from the Institute of Archaeology in Hanoi, and Dr Luan an Trong from the Thanh Hoa Culture Office, we visited Janse's old excavation sites at Dong Son ${ }^{1207}$ and the Tam-thô kilns, and the Sam Son resort where Olov and Ronny stayed in Madame Renaud's seaside establishment while they excavated at Quang-xu'o'ng. From Sam Son we travelled, as Olov and Ronny once did, in a car with a chauffeur who drove through the flat landscape with lush green rice paddies on both sides to the village Lach-truong, ${ }^{1208}$ where they made the extraordinary discovery of the kneeling figurine in the spring of 1935 . We had brought the DVD copy of one of the films found in Carl Otto Janse's study, and showed a sequence from Janse's excavations to the people at the village office. A young man said that he knew someone who was old enough to remember the excavations, and rushed off on a motorbike with us following in the car closely behind. In a small farmstead not far away we were invited to the house of Nguyen Van Tan,

1206. Janse 2001.

1207. In Vietnamese: Đông-so'n.

1208. In Vietnamese: Lach-Tru'òng. 


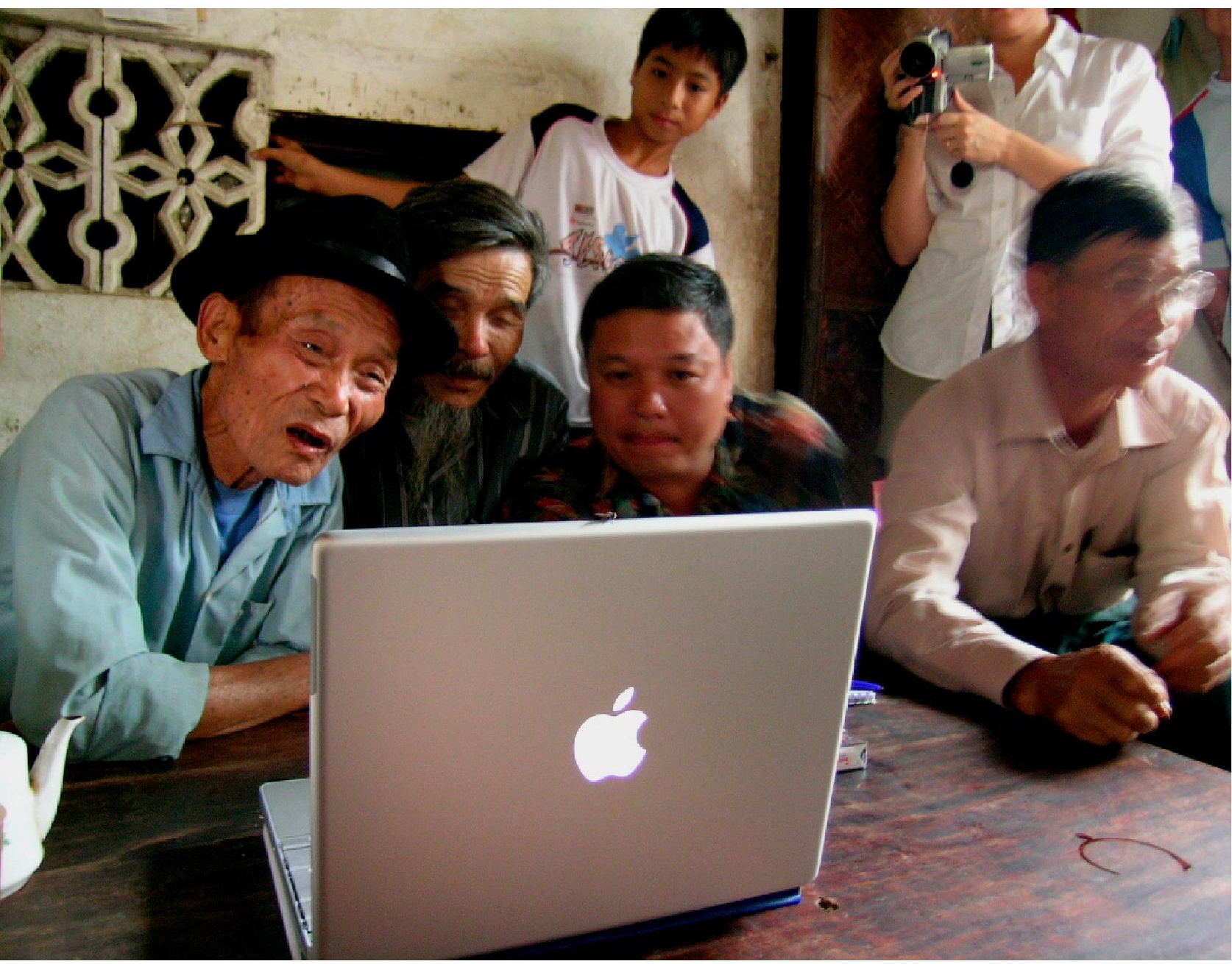

Fig. 86. Janse's film watched by Nguyen Van An in Bai Troung, October 2005 . who had witnessed the excavations as a young boy. He was 85 years old when we met, and when he watched the film on our laptop he recalled seeing foreign men and women arriving in the village and excavating two graves. Yet he did not remember any names or details, other than that they had a film camera.

After the visit to Nguyen Van Tan's house, we were invited to another house in the nearby village Bai Truong where we met Nguyen Van An, who was twelve years old when Olov and Ronny Janse arrived in his village, and remembered that they came by car along with a mandarin. Watching the film (fig. 86) he pointed at Olov Janse wearing a white trop- 
ical helmet, and said that he was a nice man who took time to tease and play with the village kids, and that he sometimes withdrew to his car to have cookies. Van An also recalled seeing vaulted brick tombs being excavated, and objects of bronze and ceramics being removed. As he watched the film he said that all his friends from that time were now dead, and that he recognized some of them on the film. He also recognized some men with weapons and the mandarin in his official outfit. The viewing attracted a crowd of people, squeezing into the room and leaning over to see the film. A scene with people dressed in bulgy coats and hats made of bamboo leaves caused outbursts of laughter, especially among the children. Mr Van An then explained that such outfits were used as protection against the sun.

The world around Lach-truong has undergone many changes since Nguyen Van An saw Olov Janse eating cookies in the car. Van An and Van Tan have lived through two wars and have had to adjust their lives to several governments with differing agendas. Their memories have offered new details and dimensions to our knowledge about Janse. And equally importantly, Janse's film and the discussions that arose when it was viewed, could add otherwise forgotten layers to the history of the villages around Lach-truong.

\section{Collections on the periphery}

Most of the artefacts that Olov Janse excavated and removed from Lachtruong and other sites around Indochina, are now found in museum collections around the world. Most of the objects brought back to France at the end of their first expedition (1934-1935) were incorporated into the collections of the Cernuschi Museum (Fig. 87). The museum was for fine Asian art rather than archaeological artefacts, so it was owing to Janse's close relationship with the museum's new director René Grousset and his steady support of Janse's expedition that the artefacts were placed there. They were used as currency and tokens of reciprocal relations, to reimburse patrons and institutions for their financial and moral support. And Janse's archaeological collection was a tremendous success when it was first put on display, at the reopening of the modernized museum in June 1935 .

The Cernuschi Museum now holds a collection of around 1,300 objects from Olov Janse's first expedition. There are mainly artefacts of bronze and pottery, but also some of stone, iron, glass, and bone. One - a ceramic 


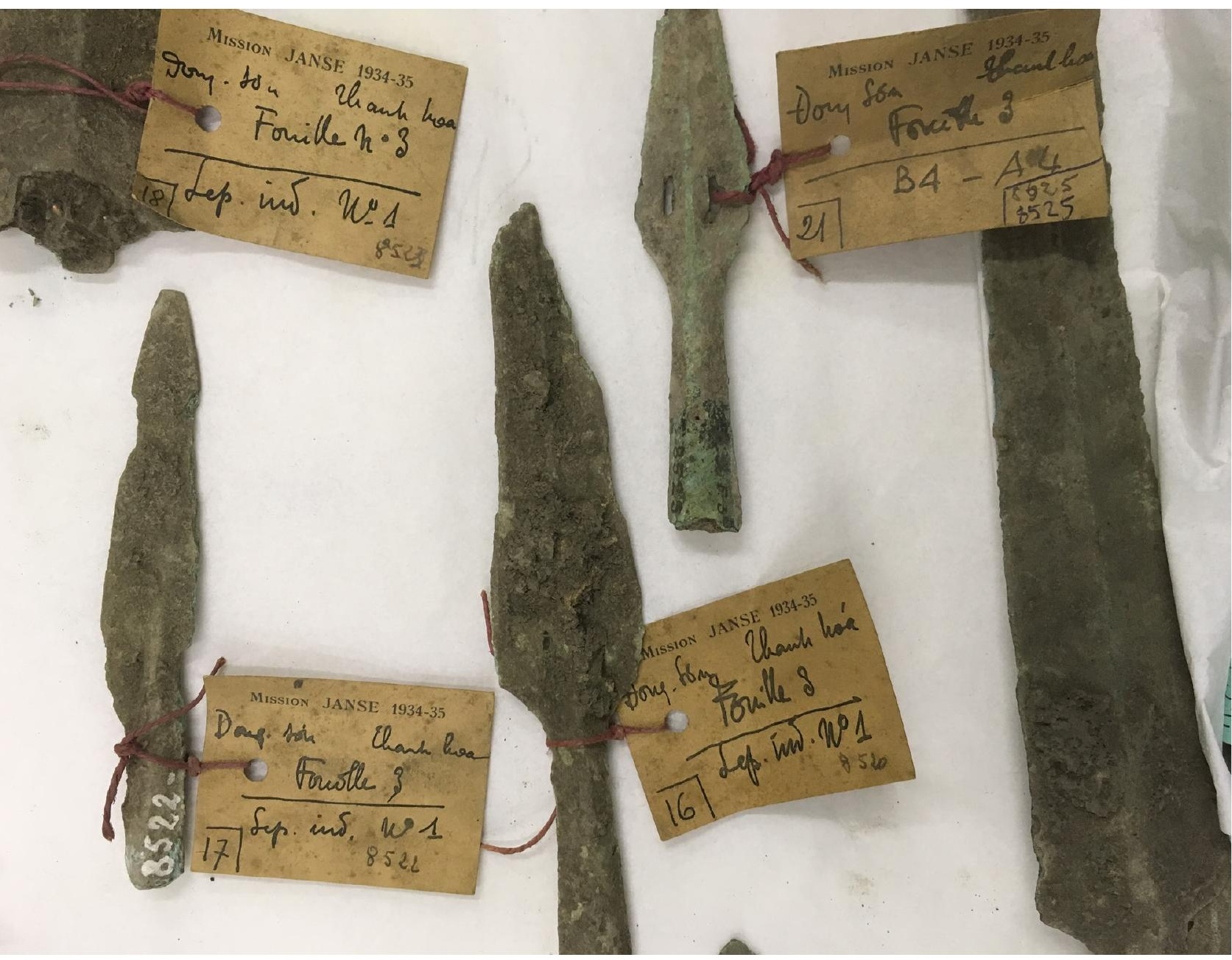

Fig. 87. Objects at Cernuschi. Photo by Anne Fort. farm model, originally used as a grave offering in one of the Han tombs Janse excavated in Indochina - is incorporated in the permanent display. We met the curator Anne Fort at the Cernuschi Museum in March 2014. She had taken an interest in Janse's collection and showed us the objects in storage and those on display. She told us that the former and present directors of the museum have expressed doubt about the value of the collection and the interest shown in it, and they have been reluctant to spend resources on it, or to use it for any major exhibitions. After the successful first display in 1935, which pointed to a new, more inclusive definition of Asian art in the Cernuschi collections, the museum has reverted to its original definition as a museum of "fine" Asian art. A misspelling 
of both Janse's names - Osvald Jansé - on signs in the display cabinet and in the store confirm the peripheral role he and his collection plays at the Cernuschi Museum today. Almost all of the objects he brought from Indochina are out of reach to the public eye in the store, and some are still in their original packing from the excavation and shipping. The latter remain uncleaned and some are in a bad state of corrosion. Thanks to Anne Fort's efforts, however, there was a small temporary display of objects from Janse's collection at the time of our visit, and the history of the collection is now described on the museum's website. ${ }^{1209}$

The artefact collection that originally arrived and was displayed at the Cernuschi Museum in 1935, was later divided into four parts. One consists of the 1,300 objects that now remain at Cernuschi. One part was transferred to the Guimet Museum, which is the national museum of Asian art in Paris. A third part of the collection was shipped back to Hanoi already in the 1930 s where it was incorporated into the collections of the Musée Louis Finot (now the National History Museum). And a fourth part of the collection was offered as a gift to the Swedish Crown Prince Gustaf Adolf in October 1935. The gift encompassed one complete ceramic vessel, 72 potsherds, 25 stone artefacts, 23 bronze objects, 34 beads, and 30 other artefacts from several of Janse's excavation sites, mostly Dong Son and Samrong Sen, and it was donated by the Crown Prince to the Museum of Far Eastern Antiquities in 1936. In $195^{\circ}$ the Guimet Museum offered the Crown Prince, who had just become King Gustaf VI Adolf, a complementary collection from Janse's excavations, which was donated to the Museum of Far Eastern Antiquities the same year. That gift encompassed 34 complete ceramic vessels, 22 potsherds, 6 stone artefacts and 221 beads. The new gift was added to the former items at the Museum of Far Eastern Antiquities, and they remain in its collections. ${ }^{1210}$ Until the late 1990 s the Museum of Far Eastern Antiquities pursued a similar official emphasis on "fine" Asian art as we saw in the Cernuschi case (somewhat paradoxically, given the geological and archaeological background of its founder, Johan Gunnar Andersson). Olov Janse's collections in Stockholm thereby met much the same destiny as the ones at the Cernuschi Museum, hidden away in the stores. When the museum was reorganized in the late 1990 s the new director, the anthro-

1209. http://www.cernuschi.paris.fr/en/collections/vietnamese-collection (accessed 3 January 2018)

1210. http://collections.smvk.se/carlotta-om/web. 
pologist Magnus Fiskesjö, was keen to increase the public knowledge about the archaeological history of the collections, and to include the hitherto ignored Southeast Asian parts of the museum's collections. ${ }^{1211}$ So, during a couple of years in the early 2000 s, Olov Janse's collections were digitized, researched and used in a small temporary display. ${ }^{1212}$ Apart from that effort, Janse's collection at the Museum of Far Eastern Antiquities remains little known.

Another collection on the periphery is that housed by the Peabody Museum of Archaeology and Ethnology at Harvard University. The collection, which ended up there as a permanent deposition following an agreement with the Harvard-Yenching Institute in 1941, included more than eleven thousand objects from Indochina, ${ }^{1213}$ two hundred beads from Johore, and almost four hundred objects from the Philippines. ${ }^{1214}$ Over six thousand objects from the original collection from Indochina were later returned to the History Museum in Saigon (then South Vietnam) in $1962,{ }^{1215}$ so the remaining collection consist of around five thousand objects - mostly potsherds - from Olov Janse's work in Indochina and the Philippines. In connection with the return of parts of the collection to Vietnam in the early 1960 s, Janse donated a set of original slides with on-site photos of artefacts and excavations at Sa Huynh and the Philippines to the Peabody Museum, where they are now accessible for online search. ${ }^{1216}$ Similar to Janse's artefact collection at the Cernuschi Museum, the Peabody collection has barely been used since it was

1211. Anna Källén worked on a temporary assignment at the Museum of Far Eastern Antiquities at this time, and was in charge of the inventory and digitization of the Southeast Asia collections, including the Janse collection.

1212. Prior 2003, Karlström \& Fiskesjö 2002.

1213.126 pottery vessels*, 4009 potsherds, 177 ceramic tiles*, 7 spindle whorls, 5 ear decorations, 47 iron artefacts*, 74 stone artefacts, 134 bronze or other metal objects* ${ }^{*} 83$ coins, approx. 6150 beads (of shell, glass, bone, amber, carnelian and gold), 1 large wood fragment, 1 pottery toilet box, and 146 misc. objects and artefacts. [ ${ }^{*}$ or fragments of]. Detailed list of sites and artefact types in the Peabody Museum Archive, XF_41-63_02.

1214. 126 pottery vessels, 5 parts of pottery vessels, 155 potsherds, 4 gold-plugged teeth, 49 glass bracelets, 27 spindle whorls, 1 metal fragment, 5 bone fragments, 4 stone objects, 1 iron ring and 1 shell. Detailed list of sites and artefact types in the Peabody Museum Archive, XF_41-63_02.

1215. Detailed list of artefacts in the Peabody Museum Archive, XF_41-63_01.

1216. Copy of letter to Helen Whiting from J. O. Brew, 25 September 1962, in the Peabody Museum Archive. See also https://pmem.unix.fas.harvard.edu (accessed 5 January 2018) 
first displayed in April 1942. Just like the Cernuschi display in 1935, the purpose of the Peabody display was to celebrate the triumphant homecoming of the archaeologist by showing his rich booty. The artefacts he brought back boosted the museums' prestige by enriching their collections. But the logic that led to later negligence was different at Peabody than at the European museums of "fine" Asian art. The arrangement with the Trustees of the Harvard-Yenching Institute, who wanted the prestige of a collection but had no room for it, was awkward right from the beginning. Senior Archivist Pat Kervick and Curatorial Associate Susan Haskell, who guided us through archives and storerooms on our visit to Harvard in April 2013, confirmed that Janse's collection is an odd bird in the museum, where most efforts today are spent on cases of repatriation to Native American tribes and interest groups. Hence the Peabody Museum, with its focus on American archaeology and ethnology, was destined to become a passive container for Janse's collection. There it now sits silently in the stores, with its giant jars, potsherds, and bronze fragments. The museum has welcomed researchers, but only a few have taken an interest in the collection. ${ }^{1217}$

If Janse's archaeological collections are largely unknown, his ethnographic collections are even more invisible. He used etnographica in much the same way as he used archaeological artefacts - as a form of currency to repay patrons and institutions for their investments in his expeditions, and as a means to attract media attention to his endeavours. Considering the support Janse received from Marcel Mauss, who was a leading actor at the Musée d'Ethnographie de Trocadéro (MET) at the time, it was only logical that some of his ethnographic collections from the first Indochina expedition ended up in Paris. Today there is a small collection of ethnographic objects originating from the expedition 1934-35 at the Musée du Quai Branly. It was transferred to Quai Branly at the opening of the new museum in 2006 , along with the other national collections of ethnography that had previously been housed by the MET (18781937) and Musée de l'Homme (1937-2006). There are 108 objects in total from Janse's expedition, and none of them have been on display. Most are objects made of perishable materials; bamboo, wood, silk and paper,

1217. In addition to these larger collections, there is according to information on Wikipedia (https://en.wikipedia.org/wiki/Olov_Janse) also a small collection from Janse at the National Museum of Singapore (previously the Raffles Museum). We have not been able to verify this information. 
and all but seven have an accession number from $1935 .{ }^{1218}$ Six objects were added in 1947 (when Janse was back in Paris for the first time after the war, and was spending his spare time searching the attics of friends and museums for hidden belongings). ${ }^{1219}$ One final object, a keepnet, was added in 1961.

But the largest collection of ethnographica after Janse's Indochina expeditions is kept at Etnografiska museet - the Ethnographic Museum in Stockholm. ${ }^{1220}$ Even though almost all the funding for the first expedition came from museums and patrons in France, Janse's intention was to use collections (first the prospect of, later as real gifts) to enhance his professional position and reputation in Sweden as well. When the archaeological collections from the first expedition were already bound to go to the Cernuschi Museum in Paris, it was mainly the ethnographic collections that he was able to offer to the Swedish museums. Through contacts with Gerhard Lindblom, Director of the Ethnographic Department of the Museum of Natural History, he arranged for a collection to be sent directly to Stockholm after the first expedition. The collection arrived in Stockholm in 1935, just after the museum had been divided from the Museum of Natural History and become Statens etnografiska museum - the National Museum of Ethnography. Janse's collection was put on temporary display in October 1936, along with two other new collections of objects from China, Japan, and East Turkestan. The collection has never been displayed again, but it is still kept at the museum (now Etnografiska museet) under the name Professor Olof [sic] Janses samlingar frän franska Indokina insamlade arren 1934-1935. ${ }^{1221}$ The collection contains 301 objects from Janse's first expedition, and is divided into four parts: (i) Archaeological artefacts from Samrong Sen (Cambodia); (ii) Sung period ceramics; (iii) Collection from Cambodia; and (iv) Collection from various parts of Indochina. The archaeological artefacts from Samrong Sen and Sung period ceramics (AD 960-1279) are both curious choices for an ethnographic collection, and suggest that the temporal aspect was

1218. http://www.quaibranly.fr/fr/explorer-les-collections.

1219. The six objects added in 1947 were two fire steels from Kunming (China), one basket with lid ascribed to the Cham culture, one long-shafted machete from Vietnam, one shield made of lacquered wood from Laos, and one basketry shield from Vietnam (http://www.quaibranly.fr/fr/explorer-les-collections).

1220. http://www.varldskulturmuseerna.se/etnografiskamuseet/forskning-samlingar/ sok-i-samlingarna1/.

1221. Collection number 1935.32. 
not as important as the geographical origin of the objects. The collection from Cambodia consists of Buddhist objects collected with the help of their friend Suzanne Karpelès at the Royal Library in Phnom Penh. The fourth and largest category contains a variety of mundane objects, such as tools, jewellery, and costume details of ethnic groups around Indochina. In the museum's catalogue is a note that most of the ethnic clothing in Janse's collection had been purchased at markets, rather than on site in the villages. The provenance of the clothing is therefore uncertain and the ethnographic value is questionable. ${ }^{1222}$ The first collection was supplemented in 1947 with 59 objects from Indochina, China and Hawaii that had been stored away in Paris during the war. These objects are similar, and in some cases almost identical to those in the collection at the Quai Branly Museum. ${ }^{1223}$ Two more minor additions were later made to the collection; one earring and three finger rings from Vietnam in 1950; ${ }^{1224}$ and in 1955 a two-piece women's dress from northern Laos, purchased during Janse's third expedition. ${ }^{1225}$ At the Etnografiska museet in Stockholm there is also a collection of 147 photographs from his first two expeditions, along with a few sketches and prints. ${ }^{1226}$

\section{Collections in use}

The most important archaeological collection from Janse's work in Indochina is housed at the National History Museum in Hanoi (formerly Musée Louis Finot). We do not know how many objects there are in the collection as a whole, but we know that many of the objects that were on display at the Cernuschi Museum in 1935 were returned to the museum in Hanoi. When we visited the museum in October 2005, members of the staff said that the collection had been split up and was now registered according to other parameters than Olov Janse's name. They said that it would be possible to restore the connections through the registries, but it would require considerable efforts that we were unable to invest at the time. But the permanent display indicated that many of the most important objects from Janse's investigations are in the possession of the Hanoi

1222.http://collections.smvk.se/carlotta-em/web/object/1021410.

1223. Collections number 1947.28 and 1947.40.

1224. Collection number 1950.19 .

1225. Collection number 1955.15.

1226. ID numbers $0312 ; 0525$. 
museum (fig. 40). There was the famous kneeling figurine Janse called ljusmannen and his Pan-like associate, along with a number of iconic objects found in the Han tombs. There were also a considerable number of kettledrums and impressive bronze objects associated with the Dong Son culture. The connection with Olov Janse's name is here of little importance. ${ }^{1227}$ Emphasis is instead on the sites he and his team excavated and the cultural associations of the objects he found, particularly connections to the Dong Son culture which has been used as a glorious point of origin for the Viet people in postcolonial nation-building narratives. ${ }^{1228}$

We encountered a similar situation for Janse's collections housed by the History Museum (formerly Musée Blanchard de la Brosse) in Ho Chi Minh City (formerly Saigon). We know that over 6000 objects from the third expedition were returned to Indochina and received by the History Museum in Saigon in 1962. ${ }^{1229}$ But at our visit to the museum in 2005 no one was able, or willing, to give information about the present whereabouts of these objects. Our communication with these two museums has been hindered by us not speaking or reading Vietnamese. But the impression remains that there is a definite difference between the European and US approach which is more person-oriented, and a Vietnamese approach to the same collections, which is depersonalized in terms of the archaeologist in charge, and much more focused on the sites or cultural associations of the objects. This does not necessarily mean that Olov Janse and his expeditions are unknown or of no interest in contemporary Vietnam. All archaeologists we have met in Vietnam were well aware of his work, and the translation of his memoirs to Vietnamese by the National History Museum in Hanoi in $2001,{ }^{1230}$ indicates a broader interest in him and his work. It is just not emphasized or showcased in official

1227. The absence of direct links to Janse's name in Vietnam today can also be seen as a reaction to the lopsided French and international accounts of the history of archaeology in Indochina, where only (with very few exceptions) French or European scholars are mentioned by name. In reality, as has been demonstrated for instance by Haydon Cherry (2004), the contributions by the many native scholars at an institution like EFEO were of equal importance but remain invisible in international accounts.

1228. Hà Văn Tàn 1991; Han Xiaorong 1998.

1229.37 pottery vessels, 67 potsherds, 3 tiles, 5 spindle whorls, 5 ear decorations, 5 stone artefacts, 28 bronze artefacts, about 200 coins, some 5,900 beads, 1 pottery toilet box, and 21 miscellaneous objects, including ceramic house- and stove-models for funerary use. Detailed list of artefacts in the Peabody Museum Archive, XF_41-63_o1.

1230. Janse 2001. 


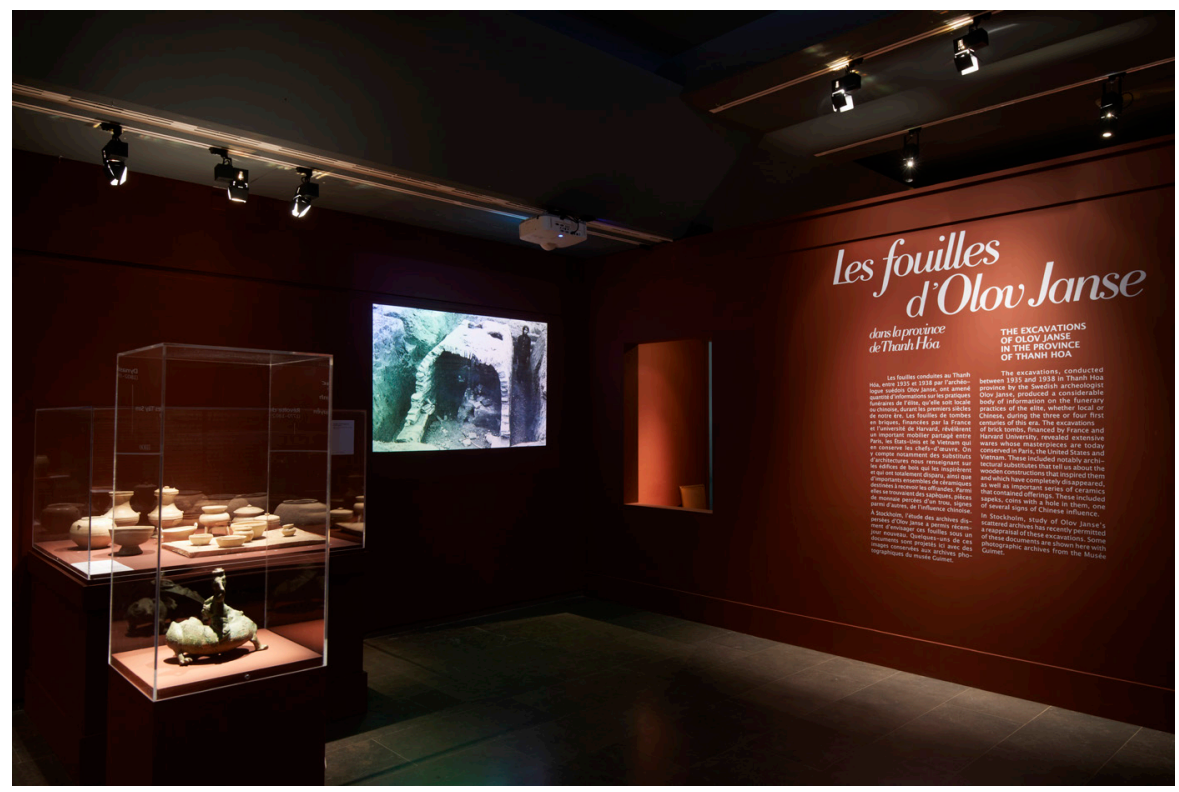

Fig. 88. Part of

the display in

the exhibition

L'Envol du

dragon at

the Guimet

Museum in

2014.

museum displays, where the objects we associate with him are used as memorabilia for other people or other contexts.

The most extensive, and most visible, collection from Janse's Indochina expeditions outside Vietnam is housed by the Guimet Museum at Place d'Iéna in Paris. Guimet is the French national museum for Asian art, and has one of the largest collections of Asian art outside of Asia. We have not been able to obtain information on the exact number of objects relating to Janse in the collections of the Guimet Museum, but we know that substantial collections from his first two expeditions to Indochina are located there. Parts of the collection were transferred from the Cernuschi Museum after the successful display following the first expedition in 1935, and it was completed after Janse's second expedition, when all excavated objects that left Indochina went to the Guimet Museum. A part of the collection was put on display in the temporary exhibition $L^{\prime} E n$ vol du dragon - Art royal du Vietnam, which showed 9 July-15 September $2014 .{ }^{1231}$ The exhibition, which was organized as part of the France-Vietnam year 2013-2014, was a collaborative effort between curators from the National History Museum in Hanoi and the Guimet Museum. Objects

1231. See exhibition catalogue "L'Envol du dragon: Art royal du Vietnam", Musée Guimet, 2014. See also http://www.guimet.fr/event/lenvol-du-dragon-art-royal-duvietnam/ (accessed 25 August 2018). 
from Janse's excavations at Dong Son and several Han brick tombs were displayed along with descriptions of his work in Indochina. The focus on Janse as a scholar, with descriptions of his contributions to the archaeological knowledge of Vietnam, was much more pronounced here than in the examples from Vietnam or the United States.

\section{The storage system}

At the Swedish History Museum in Stockholm, there are artefacts and archaeological materials connected with Janse's excavations of Swedish sites, during the earliest years of his career. ${ }^{1232}$ There is also a small collection of Stone Age artefacts from Wales that he for unknown reasons donated to the museum in $1957 .{ }^{1233}$ Until recently, there were also the artefacts belonging to the Piette collection that Janse brought to Stockholm through an obscure exchange agreement with Henri Hubert in the 1920s. They were, however, restored to the Musée d'archéologie nationale in Saint-Germain-en-Laye in 2012.

At the Swedish History Museum in Stockholm there is also a more subtle trace of Olov Janse's earliest years as a professional archaeologist. In the storerooms, archaeologists and curators still work with the system of shallow wooden trays where the artefacts are organized in carton boxes that was invented by Olov Janse and Axel Bagge in 1925. The original card index has been replaced by computer databases, but the standard procedure for the entries is very much the same. The structure, once invented in response to an unmanageable chaos in the storerooms, is now taken for granted by generations of Swedish archaeologists, us included. Few if any now connect it with Olov Janse.

\section{The archive}

The most complex and important collection of memorabilia of Olov and Renée Janse is their personal archive contained in five cardboard boxes in the Smithsonian Institution's National Anthropological Archives in Maryland, USA (fig. 2). It has been the main source of information for our research, and it has given us access to personal and professional dimensions of Olov and Renée Janse's lives without which this book could

1232. Janse 1924a; Janse 1925.

1233. Inv. nr. 25775, Swedish History Museum. 


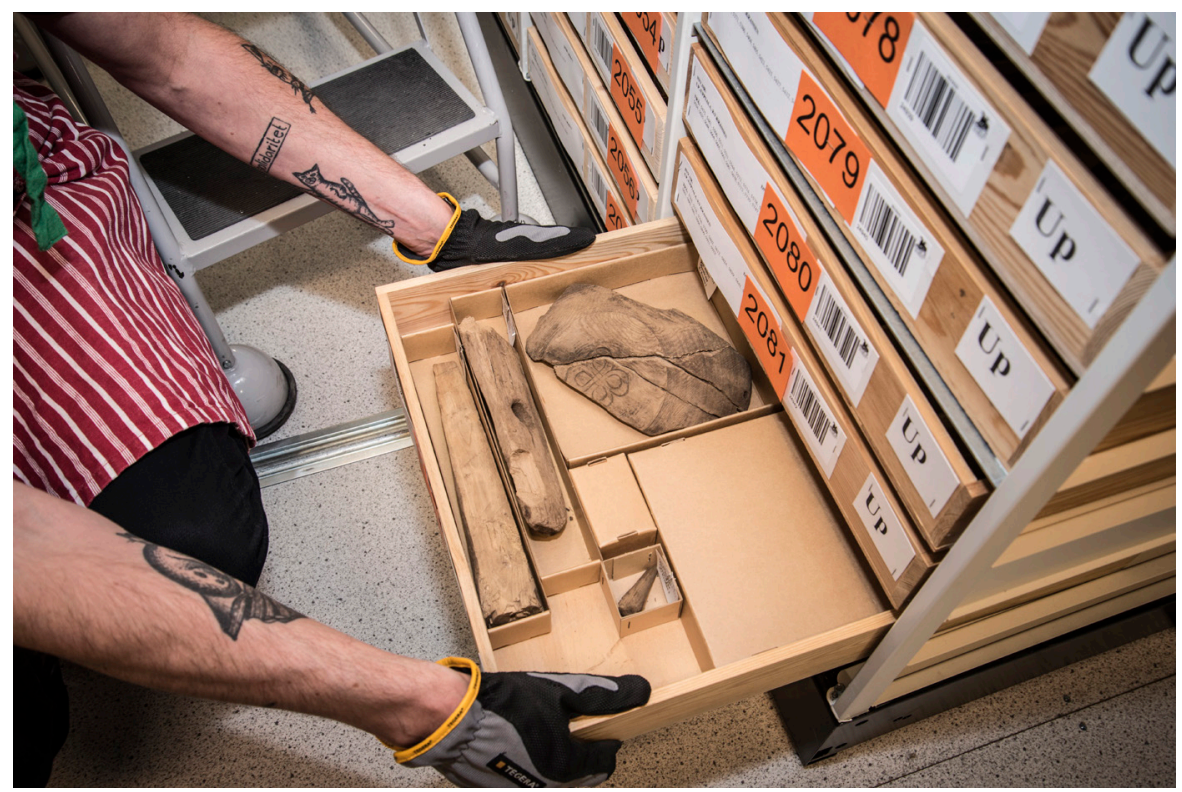

Fig. 89. The

archive at the

Swedish History

Museum is

today still based

on the system

introduced by

Janse and Bagge

in 1925

not have been written. Fragmentary pieces of information and vague indications found in this archive have pointed us in new search directions, and have helped us locate their presence in other official archives, personal memories, museum collections, and media resources on three continents. It has been invaluable for a research project that has investigated complicated and unpredictable relations across borders, between nations and institutions.

Yet it was a close call that it was not destroyed. In June 1985, Paul M. Taylor, Curator of Asian Ethnology at the Smithsonian Institution, wrote a letter to Renée Janse. Taylor had been informed about Olov's death three months earlier by their colleague and mutual friend Bill Solheim. Taylor asked Renée to consider the National Anthropological Archives as a future repository for Olov's scholarly papers. She took his advice and wrote an entry according to his letter in her testament. Fifteen years later, when Renée had died and the estate was to be settled, the Smithsonian Institution archivists were faced with the question of accepting or declining the donation. Email correspondence kept in the acquisition files tell that it was not an easy decision. ${ }^{1234}$ Who was this Olov Janse? No one had heard of him. Hence they declined parts of the material at first, but changed their minds after realizing his connection to the Smithsonian

1234. NAA: Janse 2001-29, acquisition files. 
and that Paul Taylor had approached Renée on the matter. So in the end they accepted most of the donation, apart from some old family photographs (which may very well be the photos and documents that were given to Per Janse by the family solicitor). Two archivists went with a car to Renée's old apartment in suite 530 at 4000 Massachusetts Avenue, where they met her solicitor and picked up the five boxes just before the apartment was emptied.

There are a couple of collections from Janse's work that we have been unable to locate during the course of our research. One is the collection of finds, drawings, notes, and photographs from the excavations at Dong Son that was left with Victor Goloubew in Hanoi at the end of Janse's second expedition and has not been seen since the outbreak of the Second World War and Goloubew's death in 1945. A second is a "considerable packet of notes, photographs, and reprints of articles on his archaeological research in Vietnam" that Janse reportedly gave to Bill Solheim shortly before he died, and which Solheim claims to have handed over to the Institute of Archaeology in Hanoi. ${ }^{1235}$ It is our hope that these and other materials and memories connected with Olov, Ronny and Renée Janse will turn up in the future to further enrich our understanding of their work and the contributions they made to the history of archaeology.

1235. Solheim 2002. 